\title{
Pengaruh Senam Rematik Terhadap Penurunan Nyeri Pada Pasien Rheumatoid Arthritis
}

\author{
Vanesa Tri Novana ${ }^{1 *}$, Firman Faradisi ${ }^{2}$, Nuniek Nizmah Fajriyah ${ }^{3}$ \\ 1,2,3, Program Studi Diploma Tiga Keperawatan, Universitas Muhammadiyah Pekajangan \\ Pekalongan, Indonesia \\ *email: novanavanessa@gmail.com
}

\begin{abstract}
Rheumatoid arthritis is an autoimmune disease when a person's immune system attacks the body's cells. Signs and symptoms of rheumatoid arthritis include joint inflammation and joint deformity. In most cases, patients with rheumatoid arthritis experience joint pain. Rheumatic Gymnastics is an alternative therapy that has been proven to reduce joint pain in rheumatic patients. The purpose of this case study is to describe the use of rheumatic exercise therapy in arthritic patients. The purpose of this case study is to examine therapeutic gymnastic in reducing pain among patients with rheumatoid arthritis. Two patients were taught to exercise therapeutic gymnastic. The research instrument is a pain scale observation sheet (Numerical Rating Scale). Two patients reported that there was a decreasing intensity of joint pain after doing exercise. This study concludes this particular exercise may reduce joint pain. Nursesare suggested to implement therapeutic gymnastics exercise in reducing pain amongpatients with Rheumatoid arthritis.
\end{abstract}

Keywords : rheumatoid arthritis; pain; therapeutic gymnastics exercise

\section{Abstrak}

Rematik merupakan penyakit auto imun ketika sistem imun pada tubuh seseorang menyerang sel-sel tubuhnya sendiri. Gejala rematik yaitu inflamasi, deformitas, dan nyeri sendi yang paling dirasakan oleh penderita rematik. Senam Rematik merupakan terapi alternative yang sudah terbukti dapat menurunkan nyeri sendi pada pasien rematik. Tujuan studi kasus ini adalah untuk menggambarkan penggunaan terapi senam rematik pada pasien rematik. Metode yang digunakan adalah asuhan keperawatan dengan menerapkan terapi senam rematik. Instrumen penelitian berupa lembar observasi skala nyeri (Numerical Rating Scale). Hasil yang didapatkan pada klien 1 maupun 2 yaitu mengalami penurunan nyeri. Kesimpulan pada studi kasus ini bahwa senam rematik dapat menurunkan skala nyeri. Saran bagi perawat diharapkan dapat menerapkan tindakan senam rematik untuk menurunkan skala nyeri pada pasienrematik.

Kata kunci : Rematik, nyeri, senam rematik

\section{Pendahuluan}

Menua merupakan suatu fase kehidupan yang pasti dialami setiaporang dan setiap manusia. Proses menua ditandai dengan perubahan yang meliputi anatomi dan fisiologi organ sistem, sehingga dapat mempengaruhi fungsi bagian tubuh dan kemampuan secara keseluruhan pada tubuh. Keadaandemikian tampak pula pada semua organ dan jaringan yang ada kaitannya dengan kemungkinan timbulnya beberapa masalah kesehatan akibat dari penuaan usia, salah satunya rematik. Penyakit-penyakit yang dialami lansia mengalami kenaikan seperti penyakit rematik dari 0,1 \% menjadi 0,3\% menunjukan bahwa pada orang yang berusia 55 tahun keatas banyak mengalami 


\section{Prosiding Seminar Nasional Kesehatan Lembaga Penelitian dan Pengabdian Masyarakat Universitas Muhammadiyah Pekajangan Pekalongan}

penyakit muskuloskeletal. Penyakit ini mengalami tingkat kedua setelah penyakit kardiovaskuler Suharjono, Haryono, \& Indarwati, (2019). Masyarakat Indonesia banyak yang menganggap remeh penyakit rematik karena sifatnya yang seolah-olah tidak menimbulkan kematian padahal rasa nyeri yang ditimbulkan sangat menghambat seseorang untuk melakukan kegiatan sehari-hari. Beberapa faktor yang menyebabkan penyakit rematik yaitu kegemukan yang membebani sendi, usia, jenis kelamin, infeksi, dan keturunan.

Menurut World Health Organization (WHO) mengatakan bahwa jumlah lansia tercatat sebanyak $9,77 \%$ dari jumlah total penduduk Indonesia. Hal ini dapat membuktikan bahwa perkembangan jumlah lansia diIndonesia semakin meningkat setiap tahunnya. Angka kejadian Rheumatoid Arthritis mengalami peningkatan sebanyak 355 juta jiwa dari 165 juta jiwa ditahun 2015. Prevalensi nyeri rematik sebanyak 45,59\% yang meningkat dari 39,47\% sedangkan jumlah penderita Rheumatoid Arthritis di Jawa Tengah sejumlah 11,2\% (Fajri, 2019).

Rematik merupakan penyakit autoimun ketika sistem imun pada tubuh seseorang menyerang sel-sel tubuhnya sendiri. Dalam hal ini, area persendian adalah area yang diserang oleh sistem imun pengidap rheumatoid arthritis. Akibatnya, peradangan kronik dan rasa nyeri yang hebat pada sendi-sendiyang terserang terjadi. Rheumatoid arthritis yang terus berkembang bisa menyebabkan kerusakan dan perubahan bentuk permanen pada sendi. Akibatnya pergerakan sendi mulai terbatas dan fungsi sendi bisa hilang sepenuhnya. Rematik merupakan penyakit yang familiar. Banyak orang yang mengeluhkan tentang penyakit yang biasanya diawali dengan gejala sakit padabagian persendian. Sebagian orang tidak mengetahui bahwa rematik bisa membuat kecatatan, ketidakmampuan (disabilitas), menurunkan kualitas hidup Nurwulan (2017). Rematik dapat mengancam jiwa penderitannya atau hanya menimbulkan gangguan kenyamanan dan masalah yang disebabkan oleh penyakit rematik tidak hanya berupa keterbatasan yang tampak jelas pada mobilitas hingga terjadi hal yang paling ditakuti yaitu menimbulkan kecatatan, seperti kelumpuhan gangguan aktifitas hidup sehari-hari tetapi efek sistemik yang tidak jelas dapat menimbulkan kegagalan organ dan kematian atau mengakibatkan masalah seperti rasa nyeri.

Tanda dan gejala rematik yaitu inflamasi, deformitas dan nyeri sendi yang paling sering dirasakan oleh penderita rematik (Afnuhazi, 2018). Nyeri sendi adalah suatu peradangan sendi yang ditandai dengan pembekangkan sendi, warna kemerahan, panas, nyeri dan terjadinnya gangguan gerak. Keterbatasan lansia yang tampak jelas akibat penyakit nyeri sendi yaitu kemunduran kemampuan berjalan lansia. Nyeri pada sendi membuat penderita rematik mengalami beberapa gangguan aktivitas sehingga dapat menurunkan produktivitas. Penyakit rematik banyak mengancam kemandirian dan beberapa aktivitas hidup sehari - hari penderita serta kualitas hidup. Pada lansia yang mengalami gangguan pada nyeri sendi dapat dikurangi dengan metode anggota gerak tubuh yang dapat dilakukan dengan senam rematik (Suharjono et al., 2019).

Penelitian menemukan bahwa olahraga tiga kali dalam satu minggu secara signifikan dapat memperbaiki kesehatan penderita penyakit rematik. Penerapan senam rematik untuk mengurangi nyeri sendi dan menjaga kesehatan jasmani penderita penyakit rematik. Beberapa keuntungan penerapan senam rematik tulang menjadi 


\section{Prosiding Seminar Nasional Kesehatan Lembaga Penelitian dan Pengabdian Masyarakat Universitas Muhammadiyah Pekajangan Pekalongan}

lebih lentur, otot tetap kencang dan memperlancar peredaran darah, menjaga kadar lemak dalam darah tetap normal, tidak mudah mengalami cidera dan reaksi kecepatan sel tubuh menjadi lebih baik (Nurwulan, 2017). Senam rematik dapat membantu mengurangi rasa nyeri yang dialami ataupun dirasakan oleh penderita penyakit rematik. Metode gerak tubuh dalam senam rematik juga dapat mengurangi resiko timbulnya rematik (Simanjuntak, 2018). Senam rematik ini diharapkan dapat meningkatkan kemampuan gerak, fungsi, kekuatan dan daya otot, keseimbangan sendi, biomedik sendi, dan rasa posisi sendi. Senam rematik ini ditunjukan untuk gerakkan sendi sambil meregangkan otot serta menguatkan otot - otot yang dapat membantu untuk menopang sendi - sendi dalam tubuh (Afnuhazi, 2018). Latihan rutinitas senam rematik yang periodik dapat menurunkan tingkat nyeri dan kekakuan sendi serta rasa sakit dimana dalam senam rematik terdapat unsur yang melibatkan kontraksi otot yang dinamis dan melibatkan otot sehingga hal ini dapat meningkatkan volume curah jantung. Selain itu senam rematik dapat mempengaruhi koping individu untuk mengatasi nyeri yang dirasakan karena koping ini merupakan suatu fungsi efektif yang akan membantu penderita dalam penanggulangan nyeri (Simanjuntak, 2018).

Nyeri merupakan sensasi yang rumit, unik, universal, dan bersifat individual, dikatakan bersifat individual karena respon individu terhadap sensasi nyeri beragam dan tidak bisa disamakan dengan lainnya (Kuntaraf, 2010). Menurut kuntaraf (2010) senam rematik memiliki dampak psikologis langsung yakni membantu memberi perasaan santai, mengurangi ketengangan dan meningkatkan perasaan senang karena saat senam kelenjar pituari menambah produksi beta endorpin. Senam juga mempelanjar penyaluran saraf didalam otak yaitu meningkat neurotransmitter parasimpatis (norepinephrine, dopamine, dan serotinin). Teknik senam rematik juga menormalkan denyut jantung dan tekanan darah. Riset membuktikan bahwa teknik ini meningkatkan produksi beta endorfin yang dapat mengurangi rasa nyeri pada penderita rematik (Kuntaraf 2010). Pendapat peneliti bahwa penurunan yang terjadi dipengaruhi oleh tanggapan responden yang berbeda - beda saat dilakukan senam rematik. Penurunan nyeri juga dipengaruhi oleh beberapa faktor antara lain yaitu pengalaman seseorang terhadap nyeri dan bagaimana mengatasinya, ansietas atau cemas dapat meningkatkan persepsi terhadap nyeri. Jika seorang klien menfokuskan perhatiannya pada nyeri dapat mempengaruhi persepsi nyeri. Perhatian yang meningkat dihubungkan dengan nyeri yang meningkat, sedangkan upaya distraksi dihubungkan dengan responnyeri yang menurun.

Penelitian sebelumnya yang dilakukan Rohman (2012) terkait pengaruh senam rematik untuk menurunkan nyeri lebih terbukti efektif dalam menurunkan nyeri yang terjadi, sehingga senam rematik ini dapat dijadikan sebagaialternatif penanganan nyeri pada pasien rematik.

Masih tingginya prevalensi penderita rematik dan perlunya penanganan nyeri pada pasien rematik maka penulis tertari untuk membuat karya tulis ilmiah dengan judul "Penerapan Senam Rematik Terhadap Penurunan Nyeri Pada Lansia". 


\section{Prosiding Seminar Nasional Kesehatan Lembaga Penelitian dan Pengabdian Masyarakat Universitas Muhammadiyah Pekajangan Pekalongan

\section{Literature Review}

Rheumatoid Arthritis (RA) adalah suatu penyakit autoimun inflamasi kronik yang sistemik,mengenai banyak jaringan akan tetapi pada prinsipnya menyerang sendi sertai nyeri sendi. Rheumatik dapat menyebabkan sinovitis profilatif non supuratif yang dapat merusak tulang rawan dan tulang bawahnya yang menyebabkan peradangan. Mula-mula mengenai sendi-sendi sinovial disertai dengan edema, kogesti vaskuler eksudat dan infiltrasi seluler. Apabila penyakit rheumatoid arthritis melibatkan jaringan ekstra artikular seperti kulit, jantung, pembuluh darah, otot, dan paru, rheumatoid arthritis dapat mengakibatkan lupus atau scleroderma. Arthitis (radang sendi) ada 3 jenis yang paling sering yang diderita adalah osteoarthritis, arthritis goug, dan rheumatoid arthritis yang menyebabkan benjolan pada sendi dan juga bisa menyebabkan peradangan pada sendi. Penyakit yang dapat diuraikan sebagai penyakit jaringan ikat karena mengefek rangka pendukung tubuh dan organ- organ internalnya (Saifudin, 2018).

\section{Metode}

Metode yang digunakan dalam artikel ini yaitu Studi Kasus Deskriptif. Subyek dalam artikel ini adalah 2 pasien reumatik dengan terapi senam rematik. Fokus studi ini dimaksudkan untuk membatasi studi kualitatif sekaligus membatasi penelitian guna memilih mana data yang relevan dan mana yang tidak relevan Moleong (2010). Pembatasan dalam penelitian kualitatif ini lebih didasarkan pada tingkat kepentingan/urgensi dari masalah yang dihadapi dalam penelitian ini. Penelitian ini akan difokuskan pada "Pengaruh Senam Rheumatoid Arthritis terhadap Penurunan Nyeri Pada Lansia" yang objek utamanya yaitu pada lansia. Studi kasus ini di lakukan pada pasien dengan waktu 1 minggu untuk tujuh kali kunjungan dengan pertemuan $1 x$ sehari frekuensi 15 menit melakukan tindakan keperawatan dan dilaksanakan di desa dracik kab batang pada bulan maret 2021 .

\section{Hasil dan Pembahasan}

\section{Hasil}

Klien 1

Implementasi keperawatan yang pertama dilakukan pada tanggal 19 mei 2021, jam 08.00 WIB penulis melakukan implementasi yaitu meliputi mengkaji pasien, Timbang BB, dan mengajarkan senam rematik. dan didapatkan data objektif setelah dikaji tanda tanda vital : tekanan darah 110/70, Nadi 85x per menit, pernafasan 20Xpermenit, suhu 36,6C, nyeri skala 7,berat badan $84 \mathrm{Kg}$.

Implementasi keperawatan yang ketujuh dilakukan pada tanggal 25 mei 2021, jam 08.00 WIB penulis melakukan implementasi yaitu penulis melakukan pengkajian, meliputi Timbang berat badan, Dan didapatkan data tanda-tanda vital: tekanan darah 110/70 Nadi 85x per menit, pernafasan 20Xpermenit, suhu 36C, Nyeri skala 1, berat badan $84 \mathrm{Kg}$. 


\section{Prosiding Seminar Nasional Kesehatan Lembaga Penelitian dan Pengabdian Masyarakat Universitas Muhammadiyah Pekajangan Pekalongan}

\section{Klien 2}

Implementasi keperawatan yang pertama dilakukan pada tanggal 19 mei 2021, jam 07.00 WIB penulis melakukan implementasi yaitu meliputi penulis melakukan pengkajian, didapatkan hasil klien belum mengetahui rematik sehingga penulis memberikan pendidikan kesehatan tentang rematik, mengkaji pasien, Timbang berat badan, memberikan pendidikan kesehatan tentang rematik, dan mengajarkan senam rematik. Data subyektif yang didapatkan berdasarkan pengkajian yang sudah dilakukan yaitu pasien mengatakan belum mengetahui tentang rematik.Dan didapatkan data objektif pasien tampak bingung pada saat ditanya. Dan didapatkan data tanda-tanda vital: tekanan darah 110/70 Nadi 85x per menit, pernafasan 20Xper menit, S 36,6C, Nyeri skala 4, berat badan $74 \mathrm{Kg}$.

\section{Pembahasan}

Implementasi yang penulis lakukan sesuai dengan intervensi yang penulis susun yaitu dengan menerapkan senam rematik terhadap penurunan nyeri pada penderita rematik untuk menurunkan nyeri menggunakan senam rematik dikarenakan telah terbukti dapat menurunkan nyeri. Penelitian susilowati (2012), tentang "Pengaruh Senam Rematik Terhadap Penurunan Nyeri Lansia Di Panti Wredha Dharma Bakti Pajang Surakarta" melaporkan bahwa senam rematik yang telah diberikannya mampu meningkatkan kemandirian lania yang salah satunya adalah berpindah tempat atau mobilisasi. Senam rematik dapat meningkatkan kemampuan berjalan lansia, pengaruh pada lansia penderita rematik apabila tidak melakukansenam rematik akan berdampak pada sendinya. Penelitian kedua yaitu dalam penelitian Ayu Dan Warsito (2012), hasil penelitian menunjukkan senam ini efektif mengatasi nyeri. Sama halnya dengan penelitian yang dilakukan oleh Dewi dan Prawesti (2013) yang disimpulkan bahwa senam dapat menurunkan keluhan nyeri pada lansia.

Hasil implementasi yang telah pnulis lakukan selama tujuh hari maka didapatkan hasil evaluasi bahwa pasien 1 dan 2 terjadi penurunan nyeri setelah dilakukan enam rematik. Menurut W.H.A.Mayasari (2017), senam dapat menurunkannyeri dikarenakan mampu memperlancar peredaran darah pada kaki sehingga dapat mengurangi nyeri. Gerakan aktif dan ringan tanpa menggunakan beban yang terdapat dalam senam rematik juga menjadi pemicu tubuh untuk mengeluarkan betaendorfin (senyawa kimia neuropeptida opioid lokal yang membuat seseorang merasa senang dan sebagai kekebalan tubuh).

Menurut Pfizer (2008) indikasi pemberian senam rematik yaitu klien dengan keluhan nyeri sendi, dan klien dengan riwayat Rheumatoid Artritis, adapun kontra indikasi pemberian senam rematik yaitu ibu yang menderita anemia dan mempunyai penyakit jantung dan paru-paru.

\section{Kesimpulan}

Asuhan keperawatan yang telah di lakukan oleh penulis, maka dapat di ambil kesimpulan bahwa terapi senam rematik efektif untuk menurunkan nyeri kepala pada penderita rematik. Di dapatkan hasil dari klien I dari skala nyeri 7 turun menjadi skala nyeri 0 dan pada klien I di dapatkan hasil dari skala nyeri 8 turun menjadi skala nyeri 0 . Untuk diagnosa nyeri akut pada klien I di dapatkan data subjektif yaitu klien 


\section{Prosiding Seminar Nasional Kesehatan Lembaga Penelitian dan Pengabdian Masyarakat Universitas Muhammadiyah Pekajangan Pekalongan}

mengatakan nyeri seperti tertusuk-tusuk sudah berkurang dan klien merasa lebih nyaman dan tenang. Pada klien dengan diagnosa defisit pengetahuan tentang rematik di dapatkan data subjektif klien dan keluarga mengatakan paham dan mengerti tentang penyakit rematik, dan di dapatkan data objektif yaitu klien dan keluarga nampak dapat menjelaskan kembali yang sudah dijelaskan tentang rematik.

\section{Ucapan Terima Kasih}

Dalam hal ini penulis mengucapkan terima kasih kepada Bapak Firman Faradisi dan Ibu Nuniek Nizmah F, yang telah memberikan bimbingan dan motivasi dalam penyelesaian publikasi artikel ini.

\section{Referensi}

Adistie, Fanny., Pahria, Pahria., Prawesti, Ayu., \& Triana Dewi Safariah. (2015). FaktorFaktor yang Mendukung Perilaku Merokok Mahasiswa. Jurnal Keperawatan 'Aisyiyah.JKA.2015;2(1):81-93

Afnuhazi Ridhyalla. (2018). Pengaruh senam rematik terhadap pengaruh penurunan nyeri rematik pada lansia. XII(79), 80-93

Aisyah, (2017). Deskripsi Pengetahuan Tentang Manajemen Nyeri Pada Lansia Realin Nursing Journal, Vol 2 No 3 . Diambil dari https://pjs/fdk.ac.id/index.php/Nursing/article/view/575

Ayu Dan Warsito (2012), PEMBERIAN INTERVENSI SENAM LANSIA PADA LANSIA DENGAN NYERI LUTUT, Program Studi Ilmu Keperawatan, Indonesia. Universitas Diponegoro. Semarang

Desy Nurwulan, D. 2017. Hubungan Dukungan Keluarga Dengan Tingkat Kecemasan. Pada Pasien Pre Anestesi Dengan Tindakan Spinal Anestesi di. RSUD Sleman. Poltekkes Jogjakarta

Hermayudi dan Ariani (2012). Penyakit Rematik (Reumatologi). Yogyakarta: Nuha Medika

Kuntaraf, J. dan Kuntaraf, K. 1999 Gizi Usia Lanjut. Jakarta : PT. Penerbit Erlangga. Fox, E.L. 1993. The Physiological Basic of Exercise RISKESDAS (2018). Kementrian Kesehatan Republik Indonesia.

Riskiyah, A. (2015). Nyeri Konsep dalam Praktik Keperawatan Berbaris Bukti. Jakarta : Salemba Medika

S Manurung, D Simanjuntak.. Senam Anti Stroke Pada Penderita Hipertensi. ID Patent $000,121,712,2018$

Zahro, C. \& Faiza K., (2018). Pengaruh Kompres Hangat Terhadap Penurunan Nyeri Pada Penderita Penyakit Artritis Gout, Jurnal Ners dan Kebidanan (Journal of Ners and Midwivery) Vol. 05 No. 3, 182-187 Diambil dari https://phb.ac.id/index.php/jnk/article/view/328 